\title{
ZASTOSOWANIE ANALIZY SKUPIEŃ W BADANIACH HISTORYCZNYCH NA PRZYKEADZIE WYSTĘPOWANIA CHORÓB ZAKAŹNYCH W POWIATACH WOJEWÓDZTWA POZNAŃSKIEGO W 1946 R.
}

Zarys treści: Zachowane w Archiwum Państwowym w Poznaniu statystyki zachorowań na choroby zakaźne w poszczególnych powiatach województwa poznańskiego tuż po II wojnie światowej są szczegółowe i bogate w dane liczbowe. Ich syntezę może ułatwić zastosowanie ilościowych metod grupowania. W artykule zaprezentowano możliwości, jakie daje analiza skupień, a w szczególności metoda najdalszego sasiedztwa. Uzyskane wyniki grupowania pozwoliły na usystematyzowanie wielowymiarowych informacji ilościowych, które może stanowić punkt wyjścia do szerszej interpretacji historycznej, dotyczącej zachorowań na choroby zakaźne po zakończeniu działań wojennych.

The content outline: Statistics of infectious diseases incidences soon after World War II for districts of the Poznan Voivodeship preserved in the State Archives in Poznań are detailed and rich in figures. Their synthesis is facilitated by the employment of quantitative methods of classification. The article presents possibilities offered by data clustering, in particular the method of the most distant neighbourhood. The clustering results made it possible to systematise multidimensional quantitative data and thus offered a starting point for a broader historical interpretation in the area of infectious diseases after the end of World War II.

Słowa kluczowe: analiza skupień, choroby zakaźne, grupowanie, metoda najdalszego sąsiedztwa, województwo poznańskie

Keywords: cluster analysis, infectious diseases, clustering, the most distant neighbourhood method, Poznań Voivodeship 


\section{Wstęp}

Źródła historyczne XIX i XX w. obfituja w materiały nie tylko opisowe, ale i takie, które zawierają informacje ilościowe. Niejednokrotnie historyk, obok analizy dokumentów, musi zmierzyć się z danymi liczbowymi odnoszącymi się do interesującego go zjawiska czy okresu ${ }^{1}$. W miare rozwoju instytucji statystycznych i wprowadzenia maszyn liczących źródła te stawały się coraz obfitsze. Dobrym przykładem dla opracowań krajowych tego rodzaju będą publikacje Głównego Urzędu Statystycznego wydawane pod wspólnym tytułem Historia Polski $w$ liczbach $^{2}$. Niezależnie od podjętej tematyki przed badaczem staje złożone zadanie usystematyzowania takiego materiału, uogólnienia wyników i odniesienia ich do istniejących w danym okresie okoliczności historycznych ${ }^{3}$.

Często badane obiekty - osoby, grupy społeczne czy jednostki terytorialne - można scharakteryzować za pomoca nie jednej, ale wielu cech. Przykładowo dla osób możemy wskazać miejsce ich zamieszkania, wiek, wykształcenie, narodowość, wielkość dochodów i rodzaj wykonywanej pracy. Z kolei badając efektywność społeczno-ekonomiczna jednostek terytorialnych - powiatów, województw czy państw - mamy do wyboru szeroki wachlarz wskaźników demograficznych i gospodarczych ${ }^{4}$. Analiza tego typu materiału jest stosunkowo prosta jeśli liczba cech opisujących badane obiekty ogranicza się do dwóch lub trzech. Wtedy prezentację danych ułatwia, w zależności od ich skali pomiarowej, zastosowanie histogramów, wykresów liczebności skumulowanych, wykresów pudełkowych ${ }^{5}$ oraz wykresów kołowych czy

${ }^{1}$ Zob. np.: P. Hudson, History by Numbers. An Introduction to Quantitative Approaches, London 2000; K. Narojczyk, Budowa badawczych baz danych w oparciu o historyczne źródta statystyczne, Olsztyn 2005.

2 A. Wyczański, Historia Polski w liczbach, t. 1: Państwo, społeczeństwo, Warszawa 2003; tenże, Historia Polski w liczbach, t. 2: Gospodarka, Warszawa 2006; C. Kuklo, J. Łukasiewicz, C. Leszczyńska, Historia Polski w liczbach, t. 3: Polska w Europie, Warszawa 2014.

${ }^{3}$ Zob. np.: J. Rutkowski, Zagadnienie syntezy w historii gospodarczej, w: IV Zjazd Historyków Polskich w Poznaniu 1925, Poznań 1925; J. Topolski, O zagadnieniu syntezy w historii gospodarczej, RDSG, t. 26, 1964 [1965], s. 260-265; S. Cameron, S. Richardson, Using Computers in History, New York 2005, s. 72-106.

${ }^{4}$ Zob. np. B. Podolec, Wybrane aspekty analizy warunków życia ludności w Polsce, Kraków 2014, s. 81-101; L. Frąckiewicz, M. Zrałek, Przestrzenne rozmieszczenie kwestii społecznych, Katowice 2000, s. 31-32.

5 T.L. VanPool, R.D. Leonard, Quantitative Analysis in Archeology, Oxford 2011, s. $18-40,57-58$. 
kartodiagramów ${ }^{6}$. Dla obiektów dwucechowych możliwe jest wykorzystanie wykresów rozproszenia ${ }^{7}$. W zależności od liczby cech opisujacych konkretne obiekty wykresy te będą odpowiednio dwuwymiarowe lub trójwymiarowe ${ }^{8}$. Każda z osi w takim układzie opisuje inną cechę, a badane obiekty sa punktami w przestrzeni. Im bliższe są sobie tak zdefiniowane punkty, tym większe występuje podobieństwo pomiędzy badanymi obiektami ${ }^{9}$.

Większe trudności przysparza opracowanie informacji ilościowych dotyczących badanych obiektów, które zostały opisane przez więcej niż trzy wskaźniki. Korzysta się wtedy z różnych rozwiązań: subiektywnie wybiera się cechy najważniejsze z punktu widzenia podjętej tematyki, rezygnując $\mathrm{w}$ ten sposób $\mathrm{w}$ części dostępnych i zebranych już informacji. Innym rozwiazaniem jest budowa wskaźników syntetycznych ${ }^{10}$. Powoduje to jednak, że nowa cecha, będąca kombinacją liczbową cech ją tworzących, staje się zwykle niemianowana, przez co traci interpretację. Co więcej, zawsze decyzja o algorytmie łączenia cech prostych $\mathrm{w}$ cechę syntetyczną jest decyzją subiektywną badacza.

Jednym ze sposobów grupowania obiektów wielowymiarowych, czyli takich, które zostały opisane wieloma cechami, jest analiza skupien ${ }^{11}$. Należy ona do grupy metod aglomeracyjnych. Marek Walesiak spośród licznych zalet tego podejścia wymienia działanie według jednej procedury, przez co ograniczony jest subiektywizm badacza w procesie grupowania oraz etapowy proces klasyfikacji, co z kolei ułatwia śledzenie przebiegu całego procesu ${ }^{12}$. Co więcej, wyniki analizy skupień przedstawiane sa zwykle w postaci dendrogramu, czyli drzewka połączeń, prezentującego $\mathrm{w}$ sposób przejrzysty przebieg procesu aglomeracyjnego. Niewątpliwą dogodnością tych metod jest także fakt, że algorytmy tego

${ }^{6}$ A. Błaczkowska, Metody prezentacji danych. Raporty, w: Metody wspomagajace analize danych i prezentację biznesowa, red. Ł. Wawrzynek, A. Stanimir, Wrocław 2014, s. 94-106.

7 Zob. np. S. Cameron, S. Richardson, dz. cyt., s. 125-133.

${ }^{8}$ H. Wasowicz, Metody trójwymiarowej projekcji w chronologii, w: Megabajty dziejów. Informatyka $w$ badaniach, popularyzacji i dydaktyce historii, red. R.T. Prinke, Poznań 2007, s. 63-78.

${ }^{9}$ M. Walesiak, Analiza skupień, w: Statystyczna analiza danych z wykorzystaniem programu R., red. M. Walesiak, E. Gatnar, Warszawa 2007, s. 407-408.

${ }_{10}$ M. Sobczyk, Syntetyczny miernik jakości środowiska przyrodniczego, w: Taksonomia, t. 2: Klasyfikacja i analiza danych. Problemy teoretyczne, Jelenia Góra-Wrocław-Kraków 1995, s. 89-98; L. Frąckiewicz, Zrałek, dz. cyt., s. 9-38.

11 T. Marek, Analiza skupień w badaniach empirycznych. Metody SAHN, Warszawa 1989.

${ }^{12}$ M. Walesiak, Metody analizy danych marketingowych, Warszawa 1996, s. 107. 
podejścia sa dostępne w podstawowych pakietach statystycznych, co jest ważne ze względu na złożoność obliczeń przy większej liczbie grupowanych jednostek.

Celem pracy jest prezentacja możliwości, jakie daje analiza skupień $\mathrm{w}$ badaniach historycznych. Do realizacji tego zamierzenia wybrano dane archiwalne dotyczace liczby zachorowań na choroby zakaźne w 1946 r., zebrane dla części powiatów ówczesnego województwa poznańskiego. Dane zostały zgromadzone na podstawie akt Wydziału Zdrowia Urzędu Wojewódzkiego Poznańskiego z lat 1945-1950. Wszystkie obliczenia zostały przeprowadzone w ramach pakietu Statistica. Zastosowanie analizy skupień w tym przypadku pozwoliło na wyodrębnienie obszarów w województwie poznańskim, w których uwzględnione $\mathrm{w}$ analizie choroby zakaźne występowały $\mathrm{w}$ określonym nasileniu, a także w sposób pośredni na wskazanie chorób, które różnicowały otrzymany podział.

\section{Analiza skupień}

Analiza skupien ${ }^{13}$ to jedna z ilościowych metod wielowymiarowych. Dzięki jej zastosowaniu możliwe jest łączenie wielowymiarowych obiektów (jednostek) w grupy (skupienia). W takim ujęciu każdy obiekt ma specyficzne dla siebie cechy, które można zapisać w postaci wektora i każdy wektor odpowiada jednemu obiektowi, a każda składowa w wektorze odpowiada wartości określonej cechy, charakteryzującej ten obiekt. Jeśli więc wszystkich obiektów jest $n$ i każdy opisany jest przez $p$ cech, to $i$-ty obiekt reprezentuje $p$ - wymiarowy wektor $\boldsymbol{x}_{i}$. Tworzenie grup obiektów - skupień - opiera się na porównywaniu zapisanych w ten sposób wektorów $\boldsymbol{x}_{i}, i=1,2, \ldots, n$.

$\mathrm{W}$ analizie skupień zakłada się, że liczba uzyskanych w wyniku zastosowania tej metody grup $g$ nie jest $\mathrm{z}$ góry znana, ale jest mniejsza niż liczba grupowanych jednostek, tzn. $g<n$. Co więcej, otrzymane w wyniku grupowania skupienia spełniaja warunek wewnętrznej jednorodności i zewnętrznej niejednorodności. Grupa jest jednorodna, jeżeli jednostki wchodzące w jej skład nie należą do żadnej innej grupy i różnią się znacząco od jednostek nieprzynależących do tej grupy ${ }^{14}$.

${ }^{13}$ R.M. Cormack, A Review of Classification (with Discussion), „Journal of Royal Statistical Society" A, 134, 1971, nr 3, s. 321-367; T. Marek, dz. cyt., s. 23-54; N.H. Timm, Applied Multivariate Analysis, New York 2002, s. 515-541.

${ }^{14}$ K.V. Mardia, J.T. Kent, J.M. Bibby, Multivariate Analysis, London 1979, s. 360. 
Podstawa grupowania obiektów zapisanych w postaci wektorów sa miary odległości lub podobieństwa. Sa one wielkościami skalarnymi, dzięki czemu możliwe jest wyznaczenie odległości pomiędzy każda z par badanych obiektów. Im większa jest wartość miary podobieństwa pomiędzy para obiektów, tym bardziej obiekty te uznaje się za podobne. Obiekty najbliższe, czyli najbardziej do siebie podobne, tworzą osobne skupienia. Przeciwnie interpretowana jest odległość. Im mniejsza jest jej wartość, tym obiekty są sobie bliższe. W praktyce częściej stosuje się miary odległości niż podobieństwa. W odniesieniu do obiektów charakteryzowanych cechami mierzalnymi najczęściej stosowana jest odległość euklidesowa, odległość Karla Pearsona oraz odległość taxi, inaczej zwana też odległościa miejska ${ }^{15}$. Spośród znanych procedur wyznaczania odległości metrycznych w pracy skorzystano z klasycznej odległości euklidesowej. Niech $d_{i k}$ oznacza odległość pomiędzy $i$-tym i $k$-tym obiektem:

$$
d_{i k}=\sqrt[2]{\sum_{\mathrm{r}=1}^{\mathrm{m}}\left(x_{i r}-x_{k r}\right)^{2}}, \quad \mathrm{r}=1,2, \ldots \mathrm{m} ;
$$

gdzie $\mathrm{x}_{i r}$ oraz $\mathrm{x}_{k r}$ oznacza wartość $r$-tej cechy odpowiednio $i$-tego i $k$-tego obiektu.

Na podstawie wyników porównań każdej pary obiektów budowana jest macierz odległości lub podobieństwa ${ }^{16}$. W przypadku grupowania obiektów opisanych cechami znacząco różniącymi się skalą osiaganych wartości przed wyznaczeniem odległości pomiędzy jednostkami cechy poddaje się standaryzacji ${ }^{17}$.

Ważna grupę metod analizy skupień stanowią hierarchiczne metody aglomeracyjne. Hierarchia związana jest ze szczególnym układem skupień, w którym jedne skupienia sa zawarte w drugich. W metodach tych układ skupień wskazuje na kolejność ich tworzenia. Dzięki tej hierarchii można wskazać położenie określonego skupienia, a także określić, jakie mniejsze skupienia wchodzą w skład skupienia większego, nadrzędnego.

W metodach hierarchicznych na początku zakłada się, że każdy obiekt tworzy osobne skupienie $s_{1}, s_{2}, \ldots, s_{\mathrm{n}}$, czyli liczba obiektów równa jest liczbie skupień $n=g$. W kroku pierwszym stosowania tych metod rozpatruje się $n \times n$ wymiarową macierz odległości pomiędzy wszystkimi parami obiektów. Na tej podstawie wybierana jest wartość naj-

15 Tamże, s. 376-381; W.K. Härdle, L. Simar, Applied Multivariate Statistical Analysis, Berlin-Heidelberg 2012, s. 335-337.

${ }^{16}$ Zob. np.: K.V. Mardia, J.T. Kent, J.M. Bibby, dz. cyt., s. 368; W.K. Härdle, L. Simar, dz. cyt., s. 336.

${ }_{17}$ M. Walesiak, Problemy decyzyjne w procesie klasyfikacji zbioru obiektów, „Prace Naukowe Akademii Ekonomicznej we Wrocławiu" 1010, Ekonometria 13, 2004, s. $52-71$. 
mniejsza i łączone są ze sobą dwa najbliższe sobie obiekty. W ten sposób liczba skupień zostaje zredukowana o jeden. Przed kolejnym połączeniem skupień należy w kroku drugim, korzystając z wybranego algorytmu, odpowiednio skorygować macierz odległości. W literaturze przedmiotu dostępnych jest wiele procedur wyznaczania odległości pomiędzy nowo powstałym skupieniem a pozostałymi obiektami ${ }^{18} . \mathrm{Na}$ potrzeby artykułu wybrano algorytm pełnego wiązania, który występuje także pod nazwą metody maksimum, połączeń zupełnych lub najdalszego sasiedztwa ${ }^{19}$ :

$$
d_{s_{i} ; s_{j}}=\max \left(d_{s_{i} ; s_{k}} ; d_{s_{j} ; s_{k}}\right),
$$

gdzie $d_{s_{i} ; s_{k}}$ oznacza odległość pomiędzy skupieniem $s_{i}$ oraz $s_{k}$. Dzięki tej procedurze po połączeniu w kroku pierwszym dwóch najbliższych sobie obiektów i zmniejszeniu ogólnej liczby skupień o jeden wymiar macierzy odległości również ulegnie zmniejszeniu $((n-1) \times(n-1))$. Zgodnie z wzorem (2) jako odległość nowo powstałego skupienia od pozostałych obiektów przyjmuje się największą odległość pomiędzy obiektami tworzacymi to skupienie a obiektami zewnętrznymi. W efekcie następuje równoległe powstawanie wielu zwartych skupień, które dopiero w dalszych etapach sa łaczone ${ }^{20}$.

Po odpowiedniej korekcie macierzy odległości znowu wybierana jest z niej wartość najmniejsza, na podstawie której tworzy się nowe skupienie lub dołącza nowy obiekt do powstałego wcześniej skupienia. Po tej operacji znów należy zredukować macierz odległości, stosując ten sam algorytm co w kroku drugim. Procedurę kontynuuje się do momentu włączenia wszystkich obiektów w jedno skupienie, tj. gdy $g=1$.

W wyniku zastosowania analizy skupień powstaje dendrogram, który po odpowiednim przecięciu wskazuje skład powstałych skupień oraz pokazuje moment włączenia każdego obiektu do określonego skupienia, a także moment łączenia się skupień. Najczęściej stosuje się podejście, w którym uznaje się układ skupień powstałych po przecięciu dendrogramu na poziomie połowy odległości maksymalnej lub przy pierwszym znaczącym skoku odległości pomiędzy skupieniami decydującymi o ich połączeniu ${ }^{21}$. Przydatnym narzędziem do wyznaczenia

18 Zob. np. T. Marek, dz. cyt.

19 R.M. Cormack, dz. cyt.; K.V. Mardia, J.T. Kent, J.M. Bibby, dz. cyt.; T. Marek, dz. cyt., s. 75-79; N.H. Timm, dz. cyt., s. 515-541.

20 T. Marek, dz. cyt., s. 76.

${ }^{21}$ L. Błażejczyk-Majka, R. Kala, Metody analizy skupień do charakterystyki użytków rolniczych wybranych państw unijnych i Polski, „Roczniki Naukowe Stowarzyszenia Ekonomistów Rolnictwa i Agrobiznesu” 7, 2005, s. 5-10. 
punktu przecięcia dendrogramu jest wykres przebiegu aglomeracji. Należy wspomnieć, że istnieją także bardziej złożone, numeryczne wskaźniki podziału dendrogramu ${ }^{22}$.

Analiza skupień jest szeroko stosowana we współczesnym oprogramowaniu statystycznym. Procedura ta jest udostępniana m.in. w ramach programu SAS, R czy Statistica ${ }^{23}$. W niniejszym artykule skorzystano z możliwości, jakie daje zastosowanie tej metody w ramach programu Statistica ${ }^{24}$. Grupa metod analizy skupień znajduje się w module „wielowymiarowe techniki eksploracyjne” tego programu.

\section{Obszar badań}

Prezentację zastosowania analizy skupień w badaniach historycznych przedstawiono $\mathrm{w}$ odniesieniu do liczby zachorowań na choroby zakaźne występujace na terenie wybranych powiatów województwa poznańskiego w 1946 r. Głównym źródłem danych liczbowych były akta Wydziału Zdrowia Urzędu Wojewódzkiego Poznańskiego z lat 1945-1950. Zespół ten jest przechowywany w Archiwum Państwowym w Poznaniu. Znajduja się w nim ważne dla omawianego zagadnienia cotygodniowe lub comiesięczne raporty lekarzy powiatowych z tabelarycznymi zestawieniami zachorowalności na choroby zakaźne. Często dołączane sa do nich także sprawozdania opisowe przebiegu zakażenia $^{25}$. Jan Kostrzewski podkreśla, że statystyka zachorowań i zgonów z powodu chorób zakaźnych była w pierwszych latach po wojnie bardzo niedoskonała ${ }^{26}$. Jednak spełniała ona ważną rolę miernika wyników walki z chorobami zakaźnymi. Służyła także jako wskaźnik sytuacji

${ }^{22}$ Por. A. Stanisz, Przystepny kurs statystyki z zastosowanie STATISTICA PL na przykładach z medycyny, t. 3, Kraków 2007, s. 142; J. Korzeniewski, Ocena porównawcza kilku metod wyznaczania liczby skupień $w$ zbiorze danych, „Prace Naukowe Akademii Ekonomicznej we Wrocławiu" 1126, 2006, Taksonomia, 13: Klasyfikacja $i$ analiza danych - teoria $i$ zastosowania, s. 168-174.

${ }^{23}$ Zob. np. M. Walesiak, Metody analizy...; tenże, Analiza skupień...

${ }^{24}$ A. Stanisz, dz. cyt., s. 113-164; G. Migut, Zastosowanie technik analizy skupień $i$ drzew decyzyjnych do segmentacji rynku, w: Zastosowanie nowoczesnej analizy danych $w$ marketingu i badaniach rynku, Warszawa 2009, s. 75-92.

${ }_{25}$ A. Gładysz, J. Kos, Założenia organizacyjne zapobiegania, zwalczania $i$ leczenia ostrych chorób zakaźnych na ziemiach polskich $w$ XX wieku, w: Choroby zakaźne $i$ ich zwalczanie na ziemiach polskich $w X X$ wieku, red. J. Kostrzewski, W. Magdzik, D. Naruszewicz-Lesiuk, Warszawa 2001, s. 25.

${ }^{26}$ J. Kostrzewski, Zdrowie ludności Polski w świetle danych o chorobach i zgonach, Warszawa 1977, s. 38. 
epidemiologicznej chorób, które były przedmiotem działania państwowych służb powołanych do walki z epidemiami ${ }^{27}$.

Należy przypomnieć, że w skład województwa poznańskiego ${ }^{28}$ w latach 1945-1950 wchodziły nie tylko powiaty, które do września 1939 r. znajdowały się w tym województwie, ale także z przyłączonej w czerwcu 1945 r. części Okręgu III - Pomorze Zachodnie Ziem Odzyskanych - z Piłą, Gorzowem i Zieloną Górą jako głównymi ośrodkami administracyjnymi. Pod względem terytorialnym było to w latach 1946-1950 największe województwo w Polsce. Liczyło 42 powiaty, z czego dwa miały status grodzkich, czyli miast na prawach powiatu: Poznań i Gniezno ${ }^{29}$. Przyłączone do województwa poznańskiego Ziemie Odzyskane zostały administracyjnie podzielone na 13 powiatów ${ }^{30}$, a historyczny obszar województwa poznańskiego liczył ich $29^{31}$. Strukturę administracyjną województwa poznańskiego w 1946 r. ukazuje mapa 1.

W odniesieniu do 1946 r. uzyskano informacje o występowaniu chorób zakaźnych dla 23 powiatów. Większość danych ${ }^{32}$ zawartych w źródłach z Archiwum Państwowego w Poznaniu dotyczy obszaru województwa poznańskiego w granicach sprzed wybuchu II wojny światowej33. Sprawozdania epidemiologiczne lekarzy powiatowych powiatów mię-

27 Więcej na temat kształtowania się państwowych służb związanych z ochroną zdrowia obywateli tuż po zakończeniu działań wojennych na ziemiach polskich zob.: Z. Jastrzębowski, Spory o model lecznictwa. Opieka zdrowotna w koncepcjach polskiej polityki społecznej w XIX i XX wieku (do 1948 roku), Łódź 1994, s. 205-207; E. Więckowska, Zwalczanie ostrych chorób zakaźnych w Polsce w latach 1944-1950, Wrocław 2001 (Acta Universitatis Wratislaviensis, 2267), s. 19-27; A. Gładysz, J. Kos, dz. cyt.; B. Fafrowicz, W. Szarewicz-Adamczyk, J. Błędowski, Organizacja walki z epidemia gruźlicy $w$ XX wieku w kontekście stuletnich doświadczeń w województwie lubelskim (1909-2009), w: Człowiek wobec epidemii chorób zakaźnych od starożytności po czasy współczesne w świetle literatury i medycyny, cz. 19, red. E. Łoch, G. Wallner, E. Flis-Czerniak, Lublin 2011, s. 223-233.

${ }^{28}$ Rozporządzenie Rady Ministrów z dnia 29 V 1946 r. w sprawie tymczasowego podziału administracyjnego Ziem Odzyskanych, Dz. U. 1946, nr 28, poz. 177.

${ }^{29}$ H. Szczegóła, Przeobrażenia ustrojowo-społeczne na Ziemi Lubuskiej w latach 1945-1947, Poznań 1971, s. 44.

${ }^{30}$ Rozporządzenie Rady Ministrów z dnia 29 V 1946 r. w sprawie tymczasowego podziału administracyjnego Ziem Odzyskanych, Dz. U. 1946, nr 28, poz. 177.

${ }^{31}$ Dekret Polskiego Komitetu Wyzwolenia Narodowego z dnia 21 VIII 1944 r. o trybie powołania władz administracji ogólnej I-ej i II-ej instancji, Dz. U. 1944, nr 2, poz. 8, który wszedł w życie 22 sierpnia tr.

${ }^{32}$ Brakuje danych z powiatów: krotoszyńskiego, leszczyńskiego, ostrowskiego, szamotulskiego, średzkiego, śremskiego i tureckiego.

${ }^{33}$ Dekret Polskiego Komitetu Wyzwolenia Narodowego z dnia 21 VIII 1944 r. o trybie powołania władz administracji ogólnej I-ej i II-ej instancji, Dz. U. 1944, nr 2, poz. 8. 
Mapa 1. Podział administracyjny województwa poznańskiego w 1946 r.

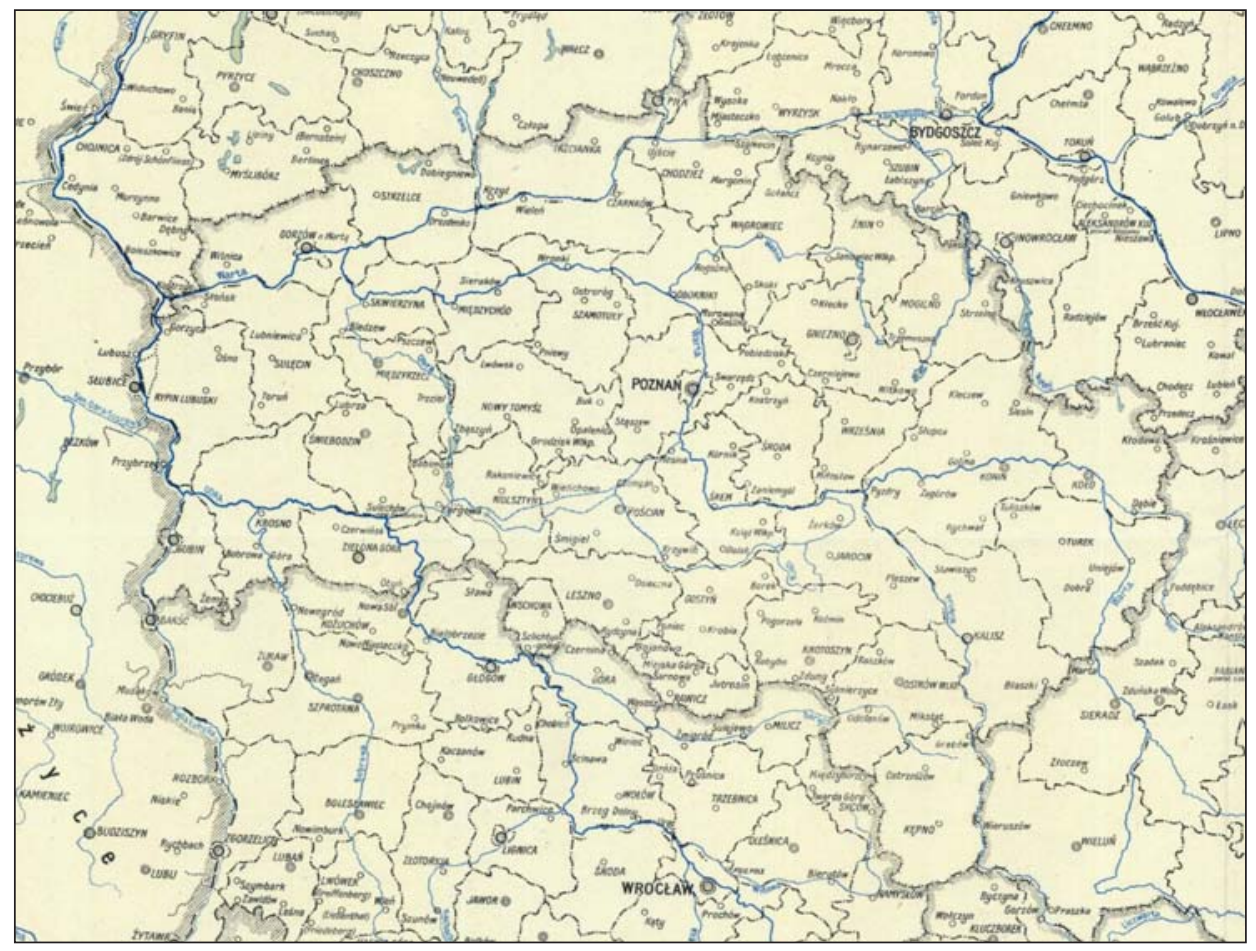

Źródło: Archiwum Map Wojskowego Instytutu Geograficznego.

dzyrzeckiego, pilskiego, trzcianeckiego i słubickiego z 1946 r. to jedyne materiały z danymi dotyczącymi Ziem Odzyskanych, które znalazły się w zespole Wydziału Zdrowia Urzędu Wojewódzkiego Poznańskiego z lat 1945-1950. Dostępne były także dane dla powiatu żnińskiego, należącego po 1950 r..$^{34}$ do województwa bydgoskiego. Brak większości danych dla powiatów leżących w obszarze Ziem Odzyskanych można tłumaczyć faktem tworzenia się dopiero polskiej administracji czy brakiem lekarza powiatowego w pierwszych miesiącach po wojnie. Może to wynikać również z tego, że sprawozdania z powiatów leżących na terenie ziemi lubuskiej mogły znaleźć się w zespole Delegatura Urzędu Wojewódzkiego Poznańskiego w Gorzowie, znajdującym się w Archiwum Państwowym w tym mieście.

Przesyłane cotygodniowe raporty o chorobach zakaźnych występujacych w powiecie zwykle miały formę gotowych formularzy, zawierających

34 Ustawa z dnia 28 VI 1950 r. o zmianach podziału administracyjnego Państwa, Dz. U. 1950, nr 28, poz. 255. 
takie informacje jak gmina i wieś, w której wykryto przypadek zachorowania. Mieściły się tam też rubryki z nazwami poszczególnych jednostek chorobowych, gdzie wpisywano liczbę zachorowań i zgonów, jakie wystapiły w danym okresie sprawozdawczym. Spośród występujących tuż po wojnie na terenie województwa poznańskiego chorób zakaźnych uwzględniono zapadalność na: dur brzuszny, dur plamisty, błonicę, gruźlicę, płonicę, jaglicę, odrę, zimnicę i różę. Przebieg każdej z wymienionych chorób został szczegółowo opisany m.in w Małej encyklopedii zdrowia $^{35}$. Zewidencjonowane przypadki zachorowań na wymienione choroby zakaźne $\mathrm{w}$ poszczególnych powiatach województwa poznańskiego w 1946 r., zebrane w Archiwum Państwowym w Poznaniu, przedstawia tabela 1.

Przyczyn występowania chorób zakaźnych po zakończeniu działań wojennych, które często rozwijały się w epidemie, było wiele. Bogata w tym zakresie literatura przedmiotu wskazuje na zmniejszona odporność wynikajacca z wyczerpania fizycznego i psychicznego, biedę i złe warunki sanitarno-higieniczne, wyniszczenie spowodowane wcześniejszym uwięzieniem w obozach koncentracyjnych ${ }^{36}$. Niewątpliwe znaczenie, szczególnie w odniesieniu do chorób przenoszących się drogą pokarmowa, miały duże ruchy ludności związane z ustanowieniem nowych granic państwa ${ }^{37}$, powrotami z obozów, ugrupowań partyzanckich czy więzień. Sytuację pogarszała dodatkowo dewastacja urządzeń wodno-kanalizacyjnych ${ }^{38}$ oraz ogólnie zły stan higieniczny kraju ${ }^{39}$.

Należy zauważyć, że rok 1946 był kolejnym rokiem walki instytucjonalnej z chorobami zakaźnymi. Już w listopadzie 1944 r. powołany został Naczelny Nadzwyczajny Komisariat do Walki z Epidemiami, podległy bezpośrednio Przewodniczącemu PKWN. Stał się on integralną częścią utworzonego w czerwcu 1945 r. Ministerstwa Zdrowia.

${ }_{35}$ Mała encyklopedia zdrowia, red. J. Wolański, E. Rużyłło, Warszawa 1973.

${ }^{36}$ M. Zaremba, Wielka trwoga: Polska 1944-1947. Ludowa reakcja na kryzys, Kraków 2012, s. 540-541.

${ }^{37} \mathrm{O}$ efektach epidemicznych masowej ucieczki ludności niemieckiej w wyniku przemieszczania się Armii Czerwonej na Zachód zob. np. N. Patyjewicz, Lęk przed epidemiami w III Rzeszy, w: Człowiek wobec epidemii..., s. 163-177.

${ }_{38}$ D. Naruszewicz-Lesiuk, W. Magdzik, Sytuacja epidemiologiczna chorób zakaźnych na ziemiach polskich $w$ XX wieku, w: Choroby zakaźne i ich zwalczanie..., s. 115.

${ }^{39}$ U. Kozłowska, Organizacja zwalczania chorób zakaźnych jako element polityki zdrowotnej państwa na Pomorzu Zachodnim (1944/45-1972), Szczecin 2013, s. 120; szczegółową charakterystykę tych czynników w odniesieniu do województwa poznańskiego zob. L. Błażejczyk-Majka, J. Miłosz, Występowanie chorób zakaźnych $w$ Wielkopolsce w latach 1945-1953 w świetle dokumentów Archiwum Państwowego w Poznaniu, „Przegląd Archiwalno-Historyczny” 3, 2016, s. 112-143. 
W tym samym roku reaktywowano także działalność Państwowego Zakładu Higieny, do którego obowiązków należało m.in. ustalanie zasad dezynfekcji, dezynsekcji oraz deratyzacji takimi środkami jak proszek DDT oraz produkcja szczepionek. Akcja szczepień ochronnych objęła około $2 \mathrm{mln}$ ludzi ${ }^{40}$. Co więcej, intensywnie zwalczano wszawicę, szczególnie z użyciem proszku DDT ${ }^{41}$. Akcje te były wspierane przez polskie ustawodawstwo ${ }^{42}$. Wydawano także okólniki ${ }^{43} \mathrm{i}$ instruk$\mathrm{cje}^{44}$ dotyczace postępowania z cierpiącymi na choroby zakaźne. Obok instytucji stacjonarnych, takich jak ośrodki zdrowia, spółdzielnie zdrowia czy izby porodowe, w wielu rejonach, szczególnie wiejskich, działało wiele „instytucji mobilnych”, realizujących cele doraźne. Można tu wymienić choćby ruchome kolumny przeciwepidemiczne ${ }^{45}$.

Jak wynika z mapy administracyjnej województwa poznańskiego, poszczególne powiaty różniły się między sobą powierzchnią (por. np. powiat pilski i krośnieński czy szamotulski). Ta cecha nie podlega badaniu w tym artykule, niewątpliwie jednak wpływa na liczbę zachorowań. W związku z tym, aby poprawić porównywalność badanych obiektów - w tym przypadku powiatów - w zakresie zapadalności na choroby zakaźne, dane zestawione $\mathrm{w}$ tabeli 1 przedstawiono $\mathrm{w}$ jednostkach względnych, czyli w przeliczeniu na $1000 \mathrm{~km}^{2}$ powierzchni całkowitej powiatu. Uzyskane w ten sposób wartości cech przedstawia tabela 2. W każdym innym przypadku lepszym punktem odniesienia dla zapadalności na choroby byłaby liczba mieszkańców, jednak ze względu na duże ruchy ludności w tym okresie odnotowaną w źródłach statystycznych liczbę ludności zamieszkującej dany teren można traktować tylko jako szacunkowa.

${ }^{40}$ AAN, Ministerstwo Zdrowia 8, k. 6, Bilans działalności i osiagnięć Ministerstwa Zdrowia, 1945 r.; M. Zaremba, dz. cyt., s. 544.

${ }^{41}$ D. Naruszewicz-Lesiuk, W. Magdziuk, dz. cyt., s. 115.

${ }^{42}$ Rozporządzenie Ministra Zdrowia z dnia 17 IV 1945 r. w sprawie przeprowadzenia przymusowych szczepień ochronnych przeciw durowi brzusznemu, Dz. U. 1945, nr 15, poz. 88; Rozporządzenie Ministra Zdrowia z dnia 2 V 1946 r. w sprawie obowiązku zgłaszania zachorowań na grypę, Dz. U. 1946, nr 9, poz. 69.

${ }^{43}$ Dla przykładu: Okólnik Ministra Zdrowia z dnia 22 XI 1945 w sprawie rejestracji chorób zakaźnych, „Dziennik Zdrowia” 1945, s. 9-10; Okólnik Ministra Zdrowia z dnia 12 II 1946 r. w sprawie przymusowej hospitalizacji i leczenia chorób zakaźnych, „Dziennik Zdrowia” 1945, nr 3, s. 26.

${ }^{44}$ Dla przykładu: Ogólna instrukcja o zwalczaniu epidemicznych chorób zakaźnych. Organizacja walki z epidemicznymi chorobami zakaźnymi na terenie wiejskim, „Dziennik Zdrowia” 1945, nr 1, s. 16 n.

${ }_{45}$ A. Gładysz, J. Kos, dz. cyt.; E. Szpak, „Chory człowiek jest wtedy jak coś go boli”. Społeczno-kulturowa historia zdrowia i choroby na wsi polskiej po 1945 r., Warszawa 2016, s. 23. 


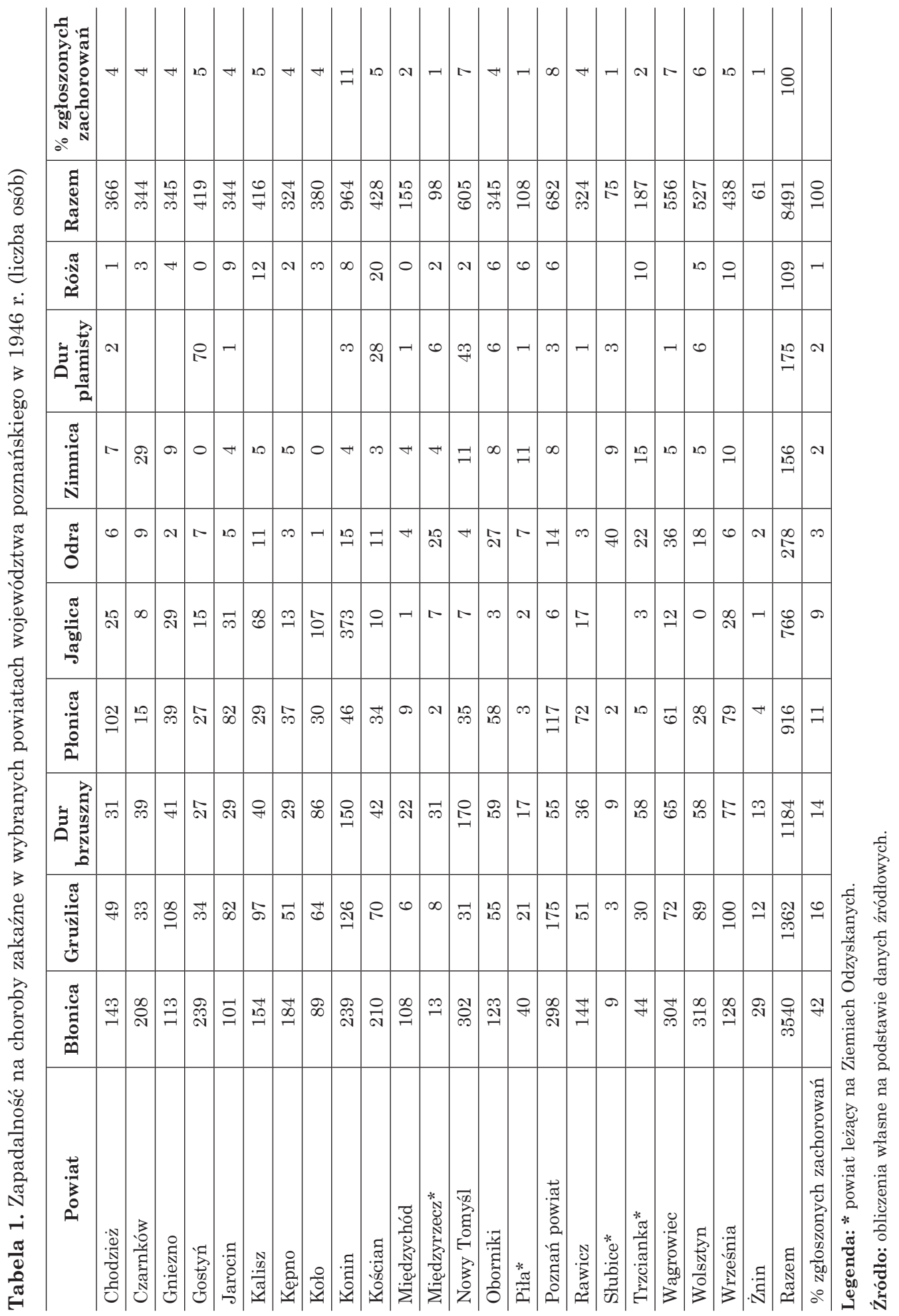




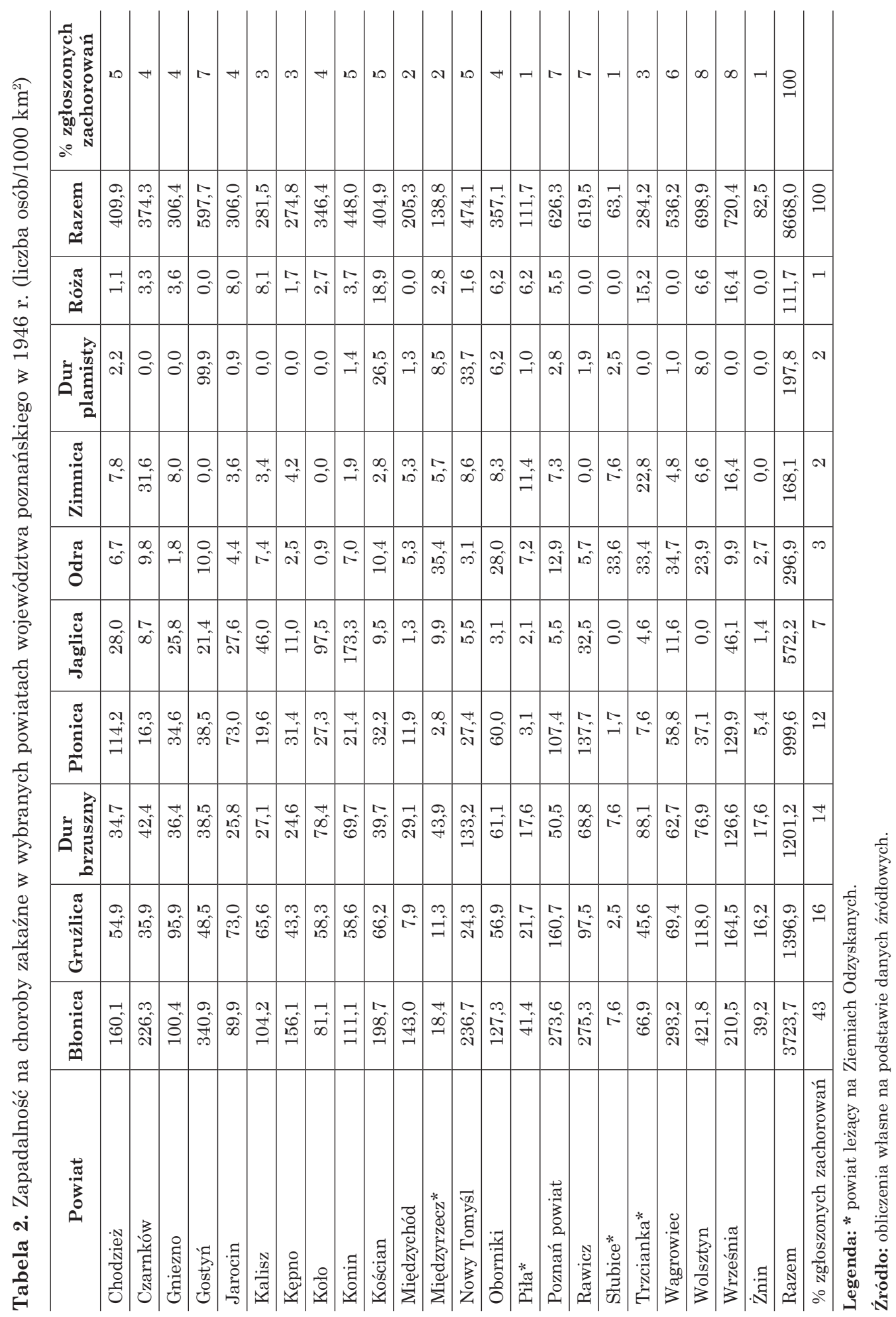




\section{Występowanie chorób zakaźnych w województwie poznańskim w 1946 r.}

Tuż po wojnie wśród osób zapadających na choroby zakaźne najwięcej odnotowano przypadków błonicy, zwanej też dyfterytem. Występuje ona najczęściej w dużych skupiskach ludzkich, zwłaszcza w mia$\operatorname{stach}^{46}$. Chorzy na tę chorobę stanowili $42 \%$ zgłoszonych zachorowań na choroby zakaźne w województwie poznańskim w 1946 r. Wysoki poziom zachorowań spowodowany był prawdopodobnie przeniesieniem się epidemii tej choroby z Niemiec. W Polsce w 1946 r. odnotowano łacznie 22510 zachorowań ${ }^{47}$. Urszula Kozłowska wskazuje, że z końcem 1945 r. najwyższy w Polce wskaźnik zapadalności na tę chorobę był właśnie w województwie poznańskim ${ }^{48}$. Niewątpliwie wpływ na tę sytuację miała droga kropelkowa zakażania tą chorobą. Z kolei Elżbieta Więckowska argumentuje, że cały obszar zachodniej Polski objęty był epidemią błonicy ze względu na uaktywnienie się starych ognisk zakażeń ${ }^{49}$. W przypadku błonicy zastosowano szczepienia ochronne. W 1946 r. wykonano ich 173870 wśród dzieci w wieku 6-12 lat na terenie całego kraju ${ }^{50}$. Na podstawie zestawionych $\mathrm{w}$ tabeli 1 danych źródłowych można zauważyć, że najwyższy poziom zachorowań na błonicę wykazano w powiatach wolsztyńskim, wagrowieckim, nowotomyskim i poznańskim.

W 1946 r. odnotowano także znaczną liczbę przypadków gruźlicy i duru brzusznego. Choroby te stanowiły odpowiednio 16 i $14 \%$ wszystkich zgłoszonych zachorowań na choroby zakaźnie w 1946 r. w województwie poznańskim. Przypadków gruźlicy było najwięcej w powiatach poznańskim, konińskim, gnieźnieńskim i wrzesińskim, a zatem $\mathrm{w}$ miejscach najbardziej zaludnionych. Ta sytuacja dokładnie wpisuje się $\mathrm{w}$ definicję przyczyn występowania tej choroby, przedstawioną np. przez Margaret Humphreys: „Gruźlica uznawana jest bowiem za chorobę rozwijająca się w środowiskach, w których panują przeludnienie, niedożywienie i brak higieny, co dotyka w szczególny sposób ludzi ubogich" ${ }^{51}$. Do dziś występowanie gruźlicy jest wyznacznikiem ubóstwa ${ }^{52}$.

\footnotetext{
${ }^{46}$ U. Kozłowska, dz. cyt., s. 132.

${ }^{47}$ A. Gałąka, Błonica, w: Choroby zakaźne i ich zwalczanie..., s. 145.

${ }^{48}$ U. Kozłowska, dz. cyt., s. 133-134.

${ }^{49}$ E. Więckowska, dz. cyt., s. 152-156.

${ }^{50}$ U. Kozłowska, dz. cyt., s. 135.

${ }^{51}$ M. Humphreys, Gruźlica: suchoty i cywilizacja, w: Wielkie epidemie $w$ dziejach ludzkości, red. K.F. Kiple, tłum. Z. Sidorkiewicz, Poznań 2002, s. 204.

${ }_{52}$ J. Aberth, Spektakle masowej śmierci. Plagi, zarazy, epidemie, tłum. L. Karnas, Warszawa 2012, s. 145.
} 
Mimo że w 1944 r. została odkryta streptomycyna, która znalazła również skuteczne zastosowanie w leczeniu gruźlicy ${ }^{53}$, tuż po wojnie liczba stwierdzanych każdego roku w całej Polsce nowych przypadków przekraczała 100 tys. Ze względu na długotrwały przebieg gruźlicy 10 lat później wskaźniki zapadalności na tę chorobę wciąż były bardzo wysokie. Z tego powodu określano ja, podobnie jak choroby weneryczne, chorobą społeczna, a więc taka, która obejmuje znaczną część populacji i stanowi jeden $\mathrm{z}$ istotniejszych elementów realizowanej przez państwo polityki społecznej ${ }^{54}$.

W walce z gruźlica Ministerstwo Zdrowa odbudowało przede wszystkim strukturę uzdrowisk przeciwgruźliczych, poradni przeciwgruźliczych, miejsc izolacji dla chronicznie chorych. Prowadzono także masowe badania oraz szczepienia przeciwgruźlicze. Szczególną opieką otoczono dzieci chore na tę chorobę ${ }^{55}$. Już w 1944 r. przy Ministerstwie Zdrowia powstał Departament do Walki z Gruźlica. Powołano wojewódzki referat do walki z gruźlica oraz powiatowych i miejskich inspektorów. W tym okresie powstała również Wojewódzka Przychodnia Przeciwgruźlicza ${ }^{56}$.

Z kolei główne źródła duru brzusznego mieściły się w powiatach nowotomyskim i konińskim. Epidemia duru brzusznego na terenach wcześniej należących do Rzeszy wynikała z tego, że ludność zarówno polska, jak i niemiecka nie uodporniła się na tę chorobę w czasie wojny ${ }^{57}$. Należy w tym miejscu przypomnieć, że dur brzuszny to choroba, która szerzy się najszybciej w środowiskach, gdzie panują złe warunki sanitarno-higieniczne. W odróżnieniu od duru plamistego przenoszonego przez wszy, dur brzuszny przeniesiony może być także przez muchy ${ }^{58}$.

Epidemia duru brzusznego po II wojnie światowej przekraczała zakresem wszystkie uprzednio obserwowane w Polsce. W 1945 r. zarejestrowano ogółem, w zależności od źródła, od 70 do ponad 80 tys. przypadków występowania tej choroby. Najwięcej zachorowań odnotowano na Ziemiach Odzyskanych. Epidemia szerzyła się tam w latach 1945-1947. Szacuje się, że na tym terenie wystapiło 75\% wszystkich

${ }^{53}$ G. Wallner, Historia chorób zakaźnych w świetle badań medycznych, w: Człowiek wobec epidemii..., s. 32 .

${ }^{54}$ J. Leowski, M. Miller, Gruźlica, w: Choroby zakaźne i ich zwalczanie..., s. 227; E. Szpak, dz. cyt., s. 262.

${ }^{55}$ U. Kozłowska, dz. cyt., s. 148-150.

${ }^{56}$ B. Fąfrowicz, W. Szarewicz-Adamczyk, J. Błędowski, dz. cyt., s. 227; więcej nt. postępowania władz państwowych w walce z gruźlicą zob. też E. Więckowska, dz. cyt., s. $82-86$.

${ }^{57}$ M. Zaremba, dz. cyt., s. 542.

${ }^{58}$ M. Humphreys, Dur brzuszny i jego nosiciele, w: Wielkie epidemie..., s. 18-26. 
zachorowań zarejestrowanych $\mathrm{w}$ tym okresie w Polsce ${ }^{59}$. Na pozostałych terenach obserwowano małe ogniska epidemiczne lub sporadyczne zachorowania zawleczone $\mathrm{z}$ terenów zachodnich lub przez repatriantów wracających z obozów koncentracyjnych ${ }^{60}$. Urszula Kozłowska wskazuje jednak, że epidemia duru brzusznego notowana w Polsce po II wojnie światowej nie miała ciagłości terenowej ${ }^{61}$. Występowały przeważnie drobne ogniska endemiczne, szczególnie na terenie miast.

Wysoki poziom zachorowań wynikał z dewastacji urządzeń sanitarno-higienicznych takich jak studnie, wodociagi, sieci kanalizacyjnej, dużej migracji ludności i ruchów wojska. Co więcej, Ewa Gonera wskazuje, że znaczna część ludności niemieckiej ukrywała chorych członków swoich rodzin ${ }^{62}$. Epidemię opanowano w ciagu dwóch lat. Głównym działaniem instytucjonalnej walki z epidemią było przeprowadzenie w $1945 \mathrm{r}$. i w kolejnych latach akcji masowych szczepień przeciwko durowi brzusznemu ${ }^{63}$. Efektem był spadek liczby zachorowań o ponad połowę.

Z kolei płonica i jaglica stanowiły około 10\% wszystkich zgłoszonych zachorowań na choroby zakaźne w badanych powiatach województwa poznańskiego. Płonica wyraźnie zdominowała zachorowania w powiatach poznańskim i chodzieskim. Ta ostra choroba zakaźna wieku dziecięcego zaliczana jest do chorób cywilizacyjnych ${ }^{64}$. Według Naczelnego Nadzwyczajnego Komisariatu do Walki z Epidemiami najwięcej zachorowań wystapiło w 1945 r. W następnym zachorowań było już nieco mniej (ponad 12500 przypadków). W kolejnych latach liczba ta drastycznie rosła, szczególnie po $1949 \mathrm{r} .{ }^{65}$ Wiązało się to przede wszystkim ze zmianami w strukturze wiekowej ludności ${ }^{66}$.

Największe ognisko jaglicy w województwie poznańskim zlokalizowane było w powiatach konińskim i kolskim. Urszula Kozłowska wskazuje, że szczególnie duże nasilenie występowania tej choroby po zakończeniu działań wojennych odnotowano na terenach Prus Wschodnich ${ }^{67}$. Jaglica jest zaliczana do chorób społecznych, której

${ }_{59}$ U. Kozłowska, dz. cyt., s. 120-121; por. J. Kostrzewski, Dur brzuszny, w: Choroby zakaźne w Polsce i ich zwalczanie w latach 1919-1962, red. J. Kostrzewski, Warszawa 1964, s. 189.

60 E. Gonera, Dur brzuszny, w: Choroby zakaźne i ich zwalczanie..., s. 196-197.

61 U. Kozłowska, dz. cyt., s. 123.

${ }^{62}$ E. Gonera, dz. cyt., s. 197.

${ }^{63}$ E. Więckowska, dz. cyt., s. 139-144.

${ }^{64}$ U. Kozłowska, dz. cyt., s. 136.

65 E. Więckowska, dz. cyt., s. 156-159.

${ }^{66}$ M.P. Czarkowski, K. Kruszewski, Ptonica, w: Choroby zakaźne i ich zwalczanie..., s. 315-317.

${ }^{67}$ U. Kozłowska, dz. cyt., s. 154-156. 
występowanie jest silnie związane $\mathrm{z}$ warunkami sanitarno-higienicznymi, zwłaszcza niewystarczającą higieną osobista, dostępem do świeżej wody. Nieleczona jaglica prowadzi do ślepoty. W walce z nią organizowano kursy i przychodnie przeciwjaglicze.

W analizowanym przykładzie zachorowalność na odrę, zimnicę, dur plamisty i różę stanowiła mniej niż 5\% zgłoszonych zachorowań. Należy pamiętać, że w przypadku odry wiele przypadków nie było zgłaszanych lekarzom. Danuta Naruszewicz-Lesiuk, powołujac się na badania Marka Saneckiego, podkreślała, że rzeczywista zachorowalność po II wojnie światowej była znacznie wyższa od tej wykazywanej w rejestrach $^{68}$. Szczególnie na wsi nie była ona uważana za ciężką chorobę, nie powodowała bowiem dużej umieralności ${ }^{69}$. Z tego powodu statystyczna liczba zgonów na odrę była najwyższa właśnie na wsi ${ }^{70}$.

Z kolei z ruchem wojsk było ściśle związanej pojawienie się na ziemiach polskich zimnicy (malarii). Występowała ona wzdłuż biegu Wisły, w obszarze tzw. przyczółków mostowych (w okolicach Sandomierza, Magnuszewa, Radzymina) ${ }^{71}$. Elżbieta Więckowska wskazuje tutaj na wpływ oddziałów wojsk niemieckich, które wcześniej wałczyły w Afryce ${ }^{72}$. Innym źródłem zakażenia byli więźniowie z krajów śródziemnomorskich przebywajacy w niemieckich obozach hitlerowskich. Co więcej, w czasie działań wojennych ogromne obszary Żuław gdańskich zalano wodą i wtedy w województwie gdańskim zanotowano ponad tysiąc przypadków zimnicy ${ }^{73}$. Z kolei służby państwowe korelowały występowanie malarii z ruchem ludności, szczególne z repatriantami. Największe nasilenie zachorowań odnotowano w latach 1946-1949 w województwach warszawskim, gdańskim, kieleckim, lubelskim, olsztyńskim i szczecińskim. W 1946 r. liczba zachorowań na terenie całego kraju wynosiła ponad 5500 .

Według ustaleń Naczelnego Nadzwyczajnego Komisariatu do Walki z Epidemiami dur plamisty występował przede wszystkim tam, gdzie przybywali repatrianci ${ }^{74}$. Rozwój tej choroby odnotowywano także w obozach koncentracyjnych i jenieckich. Wybuch epidemii był

${ }_{68}$ M. Sanecki, Odra (mor billi), w: Choroby zakaźne w Polsce i ich zwalczanie...;

D. Naruszewicz-Lesiuk, Odra, w: Choroby zakaźne i ich zwalczanie..., s. 283.

${ }^{69}$ E. Szpak, dz. cyt., s. 207.

70 Tamże, s. 208.

${ }^{71}$ U. Kozłowska, dz. cyt., s. 138-139.

72 E. Więckowska, dz. cyt., s. 79; por. M. Zaremba, dz. cyt., s. 547.

${ }^{73}$ S. Tomaszunas, J. Tomaszunas-Błaszczyk, Zimnica, w: Choroby zakaźne i ich zwalczanie..., s. 478-479.

${ }^{74}$ U. Kozłowska, dz. cyt., s. 126. 
przewidywany na zachód od Wisły, ponieważ ludność na terenach wschodnich uodporniła się na tę chorobę w czasie działań wojennych. Największe nasilenie tej choroby nastapiło w połowie $1945 \mathrm{r}$. W kolejnym roku odnotowano 3518 przypadków zachorowań, przy czym główne ogniska choroby znajdowały się w obozach pracy dla jeńców wojennych ${ }^{75}$. Dur plamisty został opanowany dzięki zmniejszeniu natężenia procesów migracyjnych oraz opanowaniu problemu wszawicy. Do poprawy sytuacji przyczyniła się niewątpliwie działania odgórne. Wśród nich można wymienić instrukcję dotycząca zasad walki z durem plamistym $^{76}$, stosowanie proszku DDT ${ }^{77}$ oraz realizację programu szczepień ochronnych, a także polepszenie warunków bytowych i likwidację obozów pracy ${ }^{78}$.

Biorąc z kolei pod uwagę powiaty, które zmagały się z największa bezwzględnie liczbą osób cierpiących na choroby zakaźne, ponownie trzeba wymienić powiaty koniński, poznański, nowotomyski, wagrowiecki i wolsztyński. Każdy z nich borykał się jednak z problemami epidemiologicznymi innego rodzaju. Najmniej przypadków takich zachorowań odnotowano natomiast w powiatach pilskim, słubickim i żnińskim. Biorąc z kolei pod uwagę liczbę zachorowań w przeliczeniu na $1000 \mathrm{~km}^{2}$, najbardziej obciążone chorobami zakaźnymi były powiaty wrzesiński, wolsztyński, poznański, rawicki i gostyński. Z kolei najzdrowszymi powiatami w 1946 r. okazały się, tak jak poprzednio, powiaty rzepecki, pilski i żniński. Przeciętny poziom zachorowań na wymienione choroby zakaźne nie różnił się znacząco od tych wyrażonych wartościami względnymi.

\section{Wyniki analizy skupień}

Jednowymiarowa analiza zachorowalności na poszczególne choroby zakaźne w rok po wojnie, na podstawie danych zestawionych w tabeli 1 , nie przysparza zwykle wielu trudności. Chcac jednak scharakteryzować

\footnotetext{
75 Tamże, s. $127-128$.

${ }^{76}$ Ogólna instrukcja o zwalczaniu epidemicznych chorób zakaźnych. Organizacja walki z epidemicznymi chorobami zakaźnymi na terenie wiejskim, „Dziennik Zdrowia" 1945 , nr 1 , s. 16 n.

77 Od duru plamistego byli niemal wolni żołnierze amerykańscy, którzy stosowali szczepionki Coxa oraz DDT, pozbywając się w tej sposób wszy. W 1947 r. okazało się, że bakterie duru plamistego leczą antybiotyki o szerokim spektrum działania; K.F. Kiple, K. Conee Ornelas, Dur plamisty: okręty i żotnierze, w: Wielkie epidemie..., s. 159. 78 U. Kozłowska, dz. cyt., s. 129-130.
} 
powiaty województwa poznańskiego przy jednoczesnym ujęciu wszystkich wskazanych chorób, należy zastosować podejście wielowymiarowe. W zaproponowanej analizie skupień badanymi obiektami były 23 powiaty województwa poznańskiego w granicach podziału administracyjnego z 1946 r. $(n=23)$. Z kolei cechami opisujacymi te obiekty sa liczby odnotowanych zachorowań na dziewięć chorób zakaźnych w 1946 r., wyrażone w liczbie zgłoszonych przez lekarzy powiatowych chorych w przeliczeniu na $1000 \mathrm{~km}^{2}(p=9)$. W ten sposób punktem wyjścia do przeprowadzenia analizy skupień była macierz o wymiarach 23 x 9 (por. dane z tab. 2). Należy podkreślić, że ze względu na jednolity charakter uwzględnionych w badaniu cech - wszystkie odnoszą się do wyrażonego w liczbie osób poziomu zachorowań - nie poddano ich standaryzacji. Na podstawie tak skonstruowanej bazy została wyznaczona macierz odległości pomiędzy jednostkami o wymiarach $23 \times 9$. Jak już wspomniano, spośród wielu dostępnych w ramach oprogramowania Statistica metryk wykorzystano odległość euklidesową (wzór 1), natomiast do korygowania macierzy odległości wybrano procedurę najdalszego sąsiedztwa (wzór 2).

Wyniki analizy skupień obrazuje dendrogram przestawiony na wykresie 1. Analizując odległość, na której nastapiło pierwsze wiązanie, można powiedzieć, że ze względu na liczbę i strukturę zachorowań w 1946 r. największym podobieństwem odznaczały się powiaty żniński i pilski (skupienie 1). Odległość między nimi mierzona metryką euklidesowa wynosiła 15,16. Obiekty te zostały połączone w pierwszym etapie. Kolejne wiązania dotyczyły powiatu międzyrzeckiego i rzepeckiego (skupienie 2) oraz kaliskiego i gnieźnieńskiego (skupienie 3). W czwartym etapie grupowania skupienie 2 przyłączone zostało od skupienia 1. Proces aglomeracji trwał do momentu aż wszystkie obiekty stworzyły jedno skupienie. Odległość pomiędzy skupieniami łączonymi w ostatnim etapie - odległość maksymalna - wynosiła 437,18.

Jak już wspomniano, aby uzyskać rozdzielne skupienia należy na odpowiednim etapie przerwać proces aglomeracji i „przeciaćc” dendrogram. Można to zrobić na poziomie połowy odległości maksymalnej (czyli na poziomie 218,59 ) lub przy pierwszym znaczącym skoku odległości pomiędzy łączonymi skupieniami (czyli na poziomie 200). W drugim przypadku przydatna jest analiza przestawionego na wykresie $2-$ wykres przebiegu aglomeracji. W omawianym przykładzie oba sposoby prowadzą do tego samego układu skupień ${ }^{79}$.

${ }^{79}$ Skupienie (Konin, Koło) zostało przyłączone do skupienia (Żnin, Piła, Słubice, Międzyrzecz, Trzcianka, Jarocin, Kalisz, Gniezno, Oborniki) na odległości 221,13. 
Wykres 1. Dendrogram przedstawiający wyniki grupowania powiatów województwa poznańskiego ze względu na liczbę zachorowań na choroby zakaźne w 1946 r.

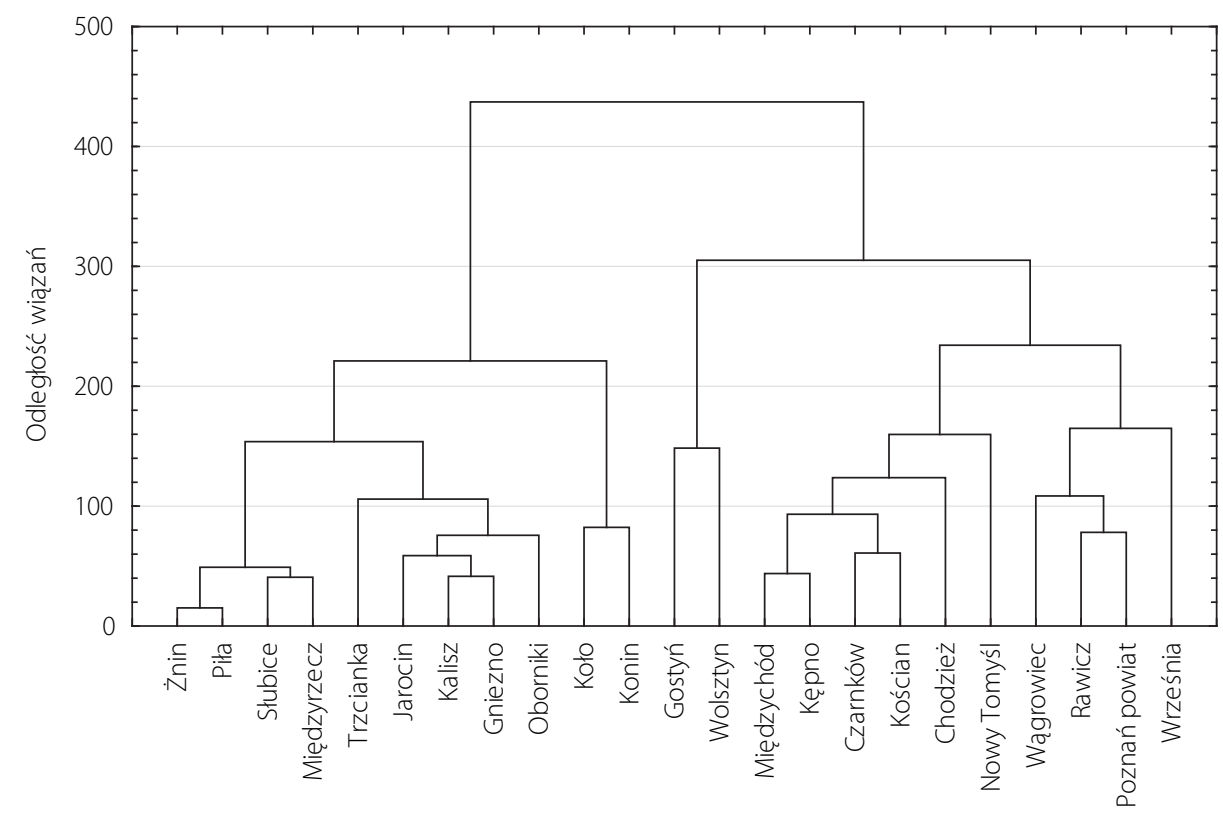

Źródło: obliczenia własne przeprowadzone w programie Statistica na podstawie danych źródłowych.

W wyniku przeprowadzonego grupowania wielowymiarowego uzyskano pięć skupień: (Września, Rawicz, Poznań, Wagrowiec), (Nowy Tomyśl, Chodzież, Kościan, Czarnków, Kępno, Międzychód), (Wolsztyn, Gostyń), (Konin, Koło), (Oborniki, Gniezno, Jarocin, Trzcianka, Kalisz, Międzyrzecz, Słubice, Piła, Żnin). Średnie poziomy zachorowalności $\mathrm{w}$ tak wyodrębnionych skupieniach powiatów zestawiono w tabeli 3 . Dodatkowo rozmieszczenie przestrzenne skupień przedstawia mapa 2.

Największą liczbę zachorowań odnotowano w skupieniu (Wolsztyn, Gostyń). Przeciętnie w 1946 r. wykazano w obu powiatach 648 przypadków zachorowań na choroby zakaźne w przeliczeniu na $1000 \mathrm{~km}^{2}$. Blisko 60\% zgłoszeń dotyczyło błonicy. W porównaniu z innymi skupieniami odnotowano $\mathrm{w}$ tych powiatach wysoki poziom zachorowań na dur plamisty (blisko 54 osoby/1000 km²) oraz grú́licę (blisko 83 osoby/1000 km²) i odrę (17 chorych/1000 km²).

Wysoki poziom zachorowań odnotowano także w skupieniu (Września, Rawicz, Poznań, Wagrowiec). Przeciętnie w powiatach je tworzacych przypadało 626 osób zakaźnie chorych na $1000 \mathrm{~km}^{2}$. Jednak w odróżnieniu od skupienia (Wolsztyn, Gostyń) na wynik ten złożyła się nie tylko wysoka liczba osób chorych na błonicę ( $42 \%$ zgłoszonych przypad- 
Wykres 2. Wykres przebiegu aglomeracji

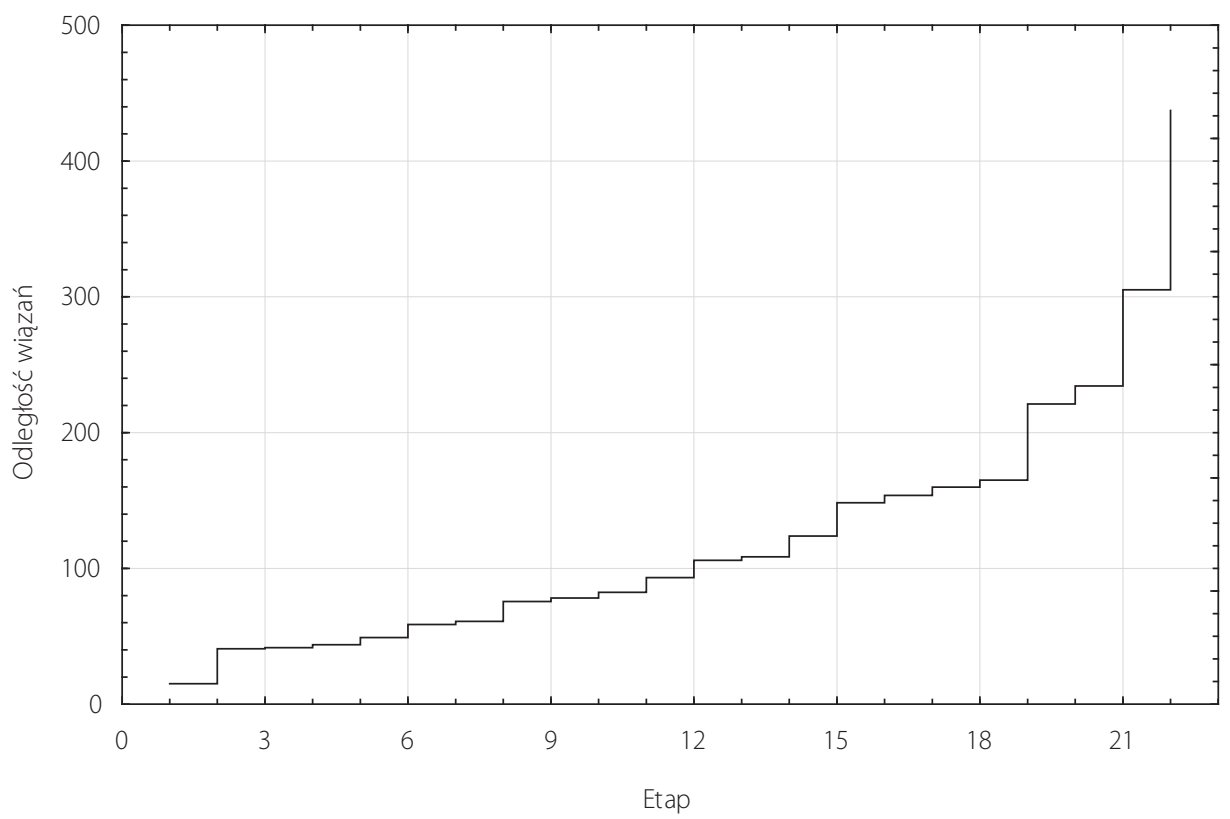

Źródło: obliczenia własne przeprowadzone w programie Statistica na podstawie danych źródłowych.

ków zachorowań), ale także na gruźlice (20\%), dur brzuszny (12\%) i płonice (17\%). W przypadku ostatnich trzech wymienionych chorób w żadnym innym skupieniu nie odnotowano tak dużej liczby zachorowań.

Dużo niższy przeciętny poziom zachorowań odnotowano w pozostałych skupieniach. I tak skupienie (Konin, Koło) odznaczało się ekstremalnie wysokim poziomem zachorowań na jaglicę i dur brzuszny. Jednak rzadziej niż w innych skupieniach występowały w tych powiatach takie choroby jak płonica, odra, zimnica i dur plamisty i róża.

Powiaty tworzace skupienie (Nowy Tomyśl, Chodzież, Kościan, Czarnków, Kępno, Międzychód) są położone na zachodnich krańcach województwa poznańskiego w granicach sprzed II wojny światowej. Odznaczają się one - w porównaniu z innymi skupieniami - wysokim poziomem zachorowań na zimnicę $(10$ osób/1000 km²) oraz najniższym poziomem występowania gruźlicy, jaglicy i odry. Ponadto wyższy niż przeciętnie okazał się poziom zachorowań na błonicę i na dur plamisty.

Najliczniejsze skupienie (Oborniki, Gniezno, Jarocin, Trzcianka, Kalisz, Międzyrzecz, Słubice, Piła, Żnin) odznacza się najniższym przeciętnym poziomem zapadalności na choroby zakaźnie. Spośród badanych powiatów należących do tego skupienia najniższe wskaź- 


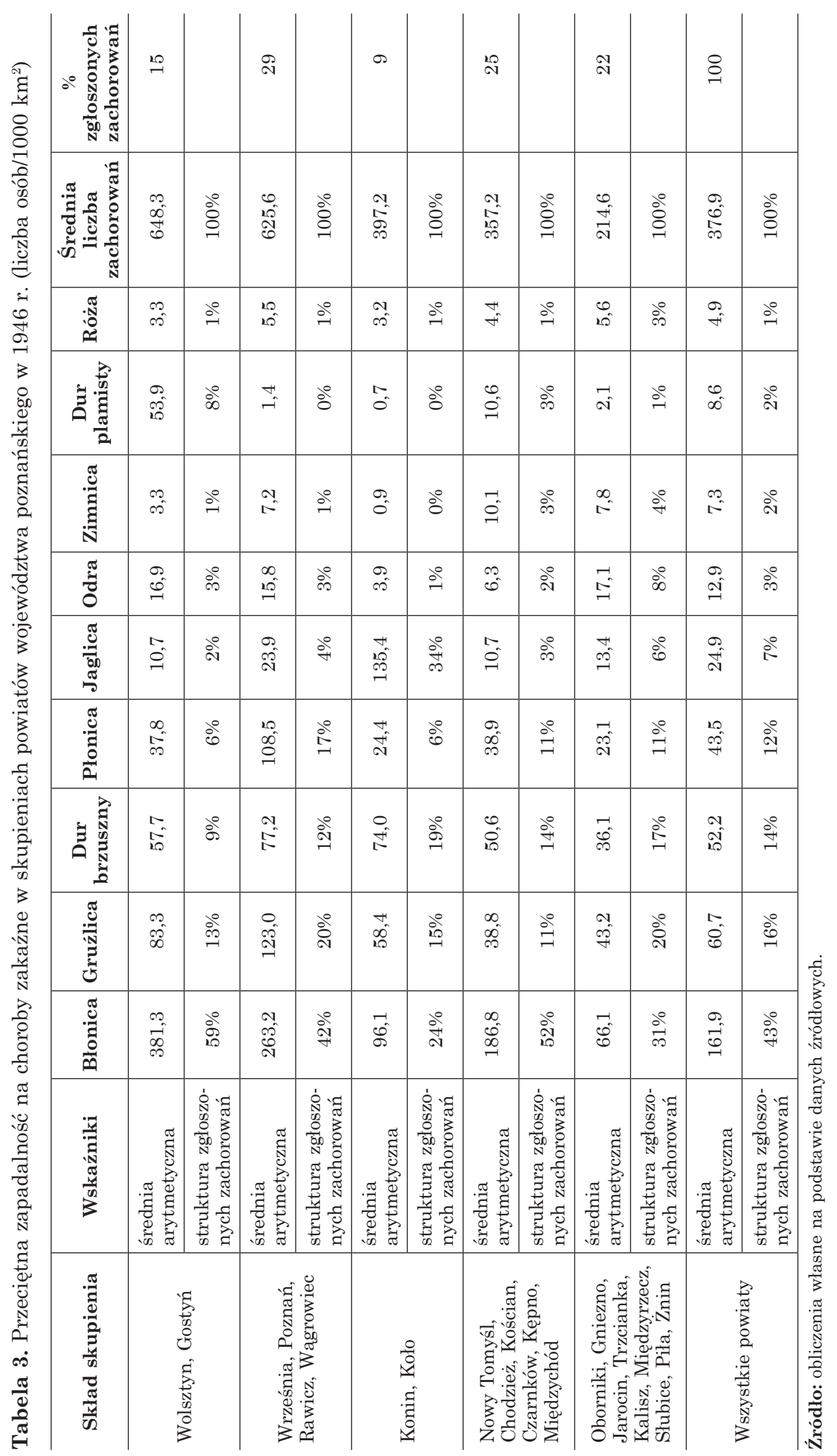


Mapa 2. Województwo poznańskie z uwzględnieniem wyników grupowania

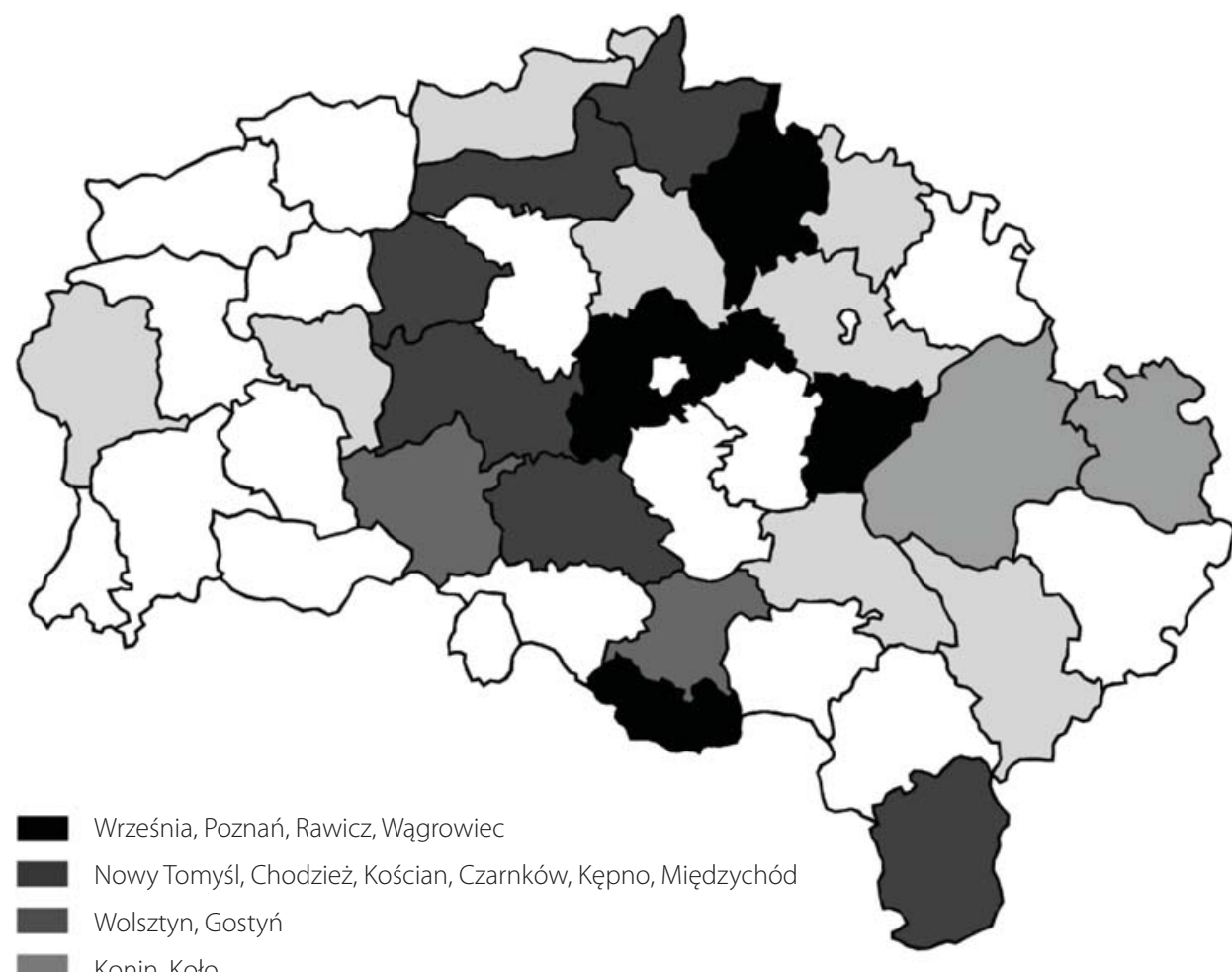

Konin, Koło

Oborniki, Gniezno, Jarocin, Trzcianka, Kalisz, Międzyrzecz, Słubice, Piła, Żnin

Brak danych

Źródło: mapa przygotowana na podstawie wyników badań.

niki zapadalności na choroby zakaźne odnotowano dla tych powiatów leżących na Ziemiach Odzyskanych, dla których udało się zgromadzić dane ilościowe. Odnotowano tutaj najniższy poziom zachorowalności na błonicę, dur brzuszny, płonicę. Z kolei choroby takie jak odra, zimnica i róża występowały tu znacznie częściej niż w pozostałych skupieniach.

\section{Podsumowanie i wnioski}

Jednym ze sposobów pozwalających na grupowanie obiektów wielocechowych jest zastosowanie analizy skupień. Co ważne, cechy opisujące obiekty mogą być wyrażone w różnych skalach: mogą to być cechy ciagłe, skokowe czy quasi-ciągłe. Dzięki określonej mierze metrycznej obliczane 
są odległości pomiędzy obiektami, tworząc w ten sposób tablicę odległości. Na jej podstawie można wskazać obiekty, które są sobie najbliższe, czyli sa do siebie najbardziej podobne. Tworza one pierwsze skupienie. Z kolei przyjęty algorytm modyfikacji macierzy odległości pozwala na kontynuację procesu grupowania. W efekcie powstaje drzewo - dendrogram. Po jego odpowiednim przecięciu można wyodrębnić skupienia badanych obiektów oraz wskazać, które obiekty były sobie najbliższe w danym skupieniu i w jakiej kolejności wchodziły w skład tego skupienia.

W wyniku zastosowania wybranej metody grupowania analizy skupień dla danych dotyczących występowania chorób zakaźnych w 1946 r. w wybranych powiatach województwa poznańskiego wyodrębniono pięć skupień. Najbliższe sobie okazały się powiaty Ziem Odzyskanych. Należały one do skupienia, które łączyło obiekty o przeciętnie najniższym poziomie występowania chorób zakaźnych. Na przeciwnym krańcu znalazło się skupienie łączące powiaty wolsztyński i gostyński oraz skupienie (Września, Poznań, Rawicz, Wagrowiec). Pierwsze z wymienionych skupień to ognisko błonicy i duru plamistego. Drugie łączyło powiaty o wyższej niż przeciętnie zachorowalności na gruźlicę i płonicę.

Z kolei powiaty kolski i koniński odznaczał się ponadprzeciętnym występowaniem jaglicy i nieco wyższej od średniej zachorowalności na dur brzuszny. Zakażenie z pewnością przeniosło się z sąsiednich powiatów północnych, gdzie panowała epidemia tej choroby. Natomiast skupienie (Nowy Tomyśl, Chodzież, Kościan, Czarnków, Kępno, Międzychód) zogniskowało zachorowania na błonicę. Rzadziej niż przeciętnie występowały tu także zachorowania na gruźlicę.

Uzyskany podział na skupienia można odnieść do sytuacji w poszczególnych powiatach województwa poznańskiego w 1946 r. Dla przykładu w Pudliszkach (powiat gostyński) istniał obóz jeniecki. Akta zgromadzone w Archiwum Państwowym w Poznaniu wskazuja, że przetrzymywani tam na przełomie stycznia i lutego $1946 \mathrm{r}$. Niemcy zachorowali na dur plamisty ${ }^{80}$. W skupieniu (Wolsztyn, Gostyń) odnotowano najwięcej przypadków zachorowań na tę chorobę.

Z kolei w Mrowinie (powiat poznański) funkcjonował obóz pracy dla ludności niemieckiej, a w Gorzowie Wielkopolskim, Pile, Poznaniu i Wagrowcu - obozy NKWD i Głównego Zarządu Informacji Wojska Polskiego ${ }^{81}$. Wszystkie wymienione powiaty, z wyjątkiem pilskiego

80 AP w Poznaniu, Urząd Wojewódzki Poznański 1945-1950, sygn. 3236, k. 16.

81 T. Wolsza, Obozy $i$ inne miejsca odosobnienia na ziemiach polskich $w$ latach 1944-1958, Warszawa 2013, http://klub-generalagrota.pl/kg/baza-wiedzy/referaty /624,dok.html (11 XII 2017). 
i gorzowskiego, znalazły się w skupieniu, które charakteryzowało się najwyższym poziomem zapadalności na choroby zakaźne, choć ich struktura, z wyjątkiem wyższego poziomu zachorowań na gruźlicę i płonicę, nie odbiegała od przeciętnej.

W literaturze przedmiotu wskazuje się także na związek liczby zachorowań z ilością tworzonych zaraz po zakończeniu działań wojennych obozów pracy, w których przetrzymywano m.in. osoby skazane na pracę przymusowa przez delegatury Komisji Specjalnej do Walki z Nadużyciami Gospodarczymi i Spekulanctwem ${ }^{82}$. W okolicach Poznania największy taki obóz znajdował się z Margoninie koło Rogoźna (powiat chodzieski). Ten ostatni znalazł się jednak w skupieniu, w którym tylko zachorowalność na błonicę przekraczała poziom przeciętny.

Niewatpliwy wpływ na rozkład geograficzny zapadalności na choroby zakaźne w $1946 \mathrm{r}$. miał także ruch repatriacyjny. Na terenie województwa poznańskiego do końca lat 40. znajdowały się dwa ważne punkty etapowe - w Poznaniu i Zbąszyniu, przez które przechodziły transporty z repatriantami ze wschodu. Z Poznania część transportów kierowana była na północ i północny zachód w kierunku Gorzowa, Piły i Szczecina. Te natomiast, które docierały do Zbąszynia, kierowano przez ten punkt na południe ziemi lubuskiej. Wraz z jeńcami wywożonymi z obozów znajdujących się na ziemiach polskich przez ówczesne województwo poznańskie wiodły szlaki transportu jeńców wojennych z ZSRR prowadzone przez NKWD. Jedna z największych epidemii tyfusu na tym terenie miała miejsce w Zbaszyniu (powiat nowotomyski) w grudniu 1945 i styczniu 1946 r. Prawdopodobnie przywieziono ja z transportem jeńców wojennych przewożonych z ZSRR do Rosyjskiej Strefy Okupacyjnej Niemiec ${ }^{83}$. Wraz z transportami repatriantów i jeńców wojennych często przemieszczały się przywleczone przez nich choroby $^{84}$. Wydaje się, że sieć linii kolejowej odpowiada miastom powiatów skupienia (Nowy Tomyśl, Chodzież, Kościan, Czarnków, Kępno, Międzychód) oraz (Września, Rawicz, Poznań, Wagrowiec).

82 B. Kopka, Obozy pracy w Polsce 1944-1950. Przewodnik encyklopedyczny, Warszawa 2002, s. 182.

${ }^{83}$ AP w Poznaniu, Prezydium Wojewódzkiej Rady Narodowej w Poznaniu, sygn. 3240, Wykaz zachorowań i zgonów Mogilno - Nowy Tomyśl - Oborniki, k. 160, Sprawozdanie lekarza powiatowego z 19 I 1945 r.

${ }^{84}$ AP w Poznaniu, Urząd Wojewódzki Poznański 1945-1950, sygn. 3250, Sprawy zwalczania duru plamistego, k. 31, Informacja lekarza powiatowego z powiatu wagrowieckiego z 19 VI 1945 r. 


\section{Bibliografia}

\section{Źródła archiwalne}

Archiwum Państwowe w Poznaniu: Urząd Wojewódzki Poznański 1945-1950; Państwowy Urząd Repatriacyjny - Oddział Wojewódzki w Poznaniu 1945$-1951$.

Archiwum Akt Nowych: Ministerstwo Zdrowia 8, k. 6, Bilans działalności i osiagnięć Ministerstwa Zdrowia, 1945 r.

Archiwum Map Wojskowego Instytutu Geograficznego.

\section{Akty prawne}

Dekret Polskiego Komitetu Wyzwolenia Narodowego z dnia 21 sierpnia 1944 r. o trybie powołania władz administracji ogólnej I-ej i II-ej instancji, Dz. U. 1944, nr 2, poz. 8.

Ogólna instrukcja o zwalczaniu epidemicznych chorób zakaźnych. Organizacja walki z epidemicznymi chorobami zakaźnymi na terenie wiejskim, „Dziennik Zdrowia" 1945 , nr 1, s. $16 \mathrm{n}$.

Okólnik Ministra Zdrowia z dnia 12 lutego 1946 r. w sprawie przymusowej hospitalizacji i leczenia chorób zakaźnych, „Dziennik Zdrowia” 1945, nr 3, s. 26.

Okólnik Ministra Zdrowia z dnia 22 listopada 1945 w sprawie rejestracji chorób zakaźnych, „Dziennik Zdrowia” 1945, s. 9-10.

Rozporządzenie Ministra Zdrowia z dnia 17 kwietnia 1945 r. w sprawie przeprowadzenia przymusowych szczepień ochronnych przeciw durowi brzusznemu, Dz. U. 1945, nr 15, poz. 88.

Rozporządzenie Ministra Zdrowia z dnia 2 maja 1946 r. w sprawie obowiązku zgłaszania zachorowań na grypę, Dz. U. 1946, nr 9, poz. 69.

Rozporządzenie Rady Ministrów z dnia 29 maja 1946 r. w sprawie tymczasowego podziału administracyjnego Ziem Odzyskanych, Dz. U. 1946, nr 28, poz. 177.

Ustawa z dnia 28 czerwca 1950 r. o zmianach podziału administracyjnego Państwa, Dz. U. 1950, nr 28, poz. 255.

\section{Opracowania}

Aberth J., Spektakle masowej śmierci. Plagi, zarazy, epidemie, tłum. L. Karnas, Warszawa 2012.

Błaczkowska A., Metody prezentacji danych. Raporty, w: Metody wspomagajace analize danych i prezentacje biznesowa, red. Ł. Wawrzynek, A. Stanimir, Wrocław 2014, s. 94-106.

Błażejczyk-Majka L., Kala R., Metody analizy skupień do charakterystyki użytków rolniczych wybranych państw unijnych i Polski, „Roczniki Naukowe Stowarzyszenia Ekonomistów Rolnictwa i Agrobiznesu" 7, 2005, s. 5-10. 
Błażejczyk-Majka L., Miłosz J., Występowanie chorób zakaźnych w Wielkopolsce $w$ latach 1945-1953 w świetle dokumentów Archiwum Państwowego $w$ Poznaniu, „Przegląd Archiwalno-Historyczny” 3, 2016, s. 112-143.

Choroby zakazne $i$ ich zwalczanie na ziemiach polskich $w X X$ wieku, red. J. Kostrzewski, W. Magdzik, D. Naruszewicz-Lesiuk, Warszawa 2001.

Choroby zakaźne $w$ Polsce $i$ ich zwalczanie $w$ latach 1919-1962, red. J. Kostrzewski, Warszawa 1964.

Człowiek wobec epidemii chorób zakaźnych od starożytności po czasy wspótczesne $w$ świetle literatury i medycyny, cz. 19, red. E. Łoch, G. Wallner, E. Flis-Czerniak, Lublin 2011.

Korzeniewski J., Ocena porównawcza kilku metod wyznaczania liczby skupień $w$ zbiorze danych, „Prace Naukowe Akademii Ekonomicznej we Wrocławiu” 1126, 2006, Taksonomia, 13: Klasyfikacja $i$ analiza danych - teoria $i$ zastosowania, s. 168-174.

Kozłowska U., Organizacja zwalczania chorób zakaźnych jako element polityki zdrowotnej państwa na Pomorzu Zachodnim (1944/45-1972), Szczecin 2013.

Marek T., Analiza skupień w badaniach empirycznych. Metody SAHN, Warszawa 1989.

Migut G., Zastosowanie technik analizy skupień $i$ drzew decyzyjnych do segmentacji rynku, w: Zastosowanie nowoczesnej analizy danych $w$ marketingu $i$ badaniach rynku, Warszawa 2009, s. 75-92.

Narojczyk K., Budowa badawczych baz danych w oparciu o historyczne źródta statystyczne, Olsztyn 2005.

Podolec B., Wybrane aspekty analizy warunków życia ludności w Polsce, Kraków 2014.

Sobczyk M., Syntetyczny miernik jakości środowiska przyrodniczego, w: Taksonomia, t. 2: Klasyfikacja i analiza danych. Problemy teoretyczne, Jelenia Góra-Wrocław-Kraków 1995, s. 89-98.

Stanisz A., Przystepny kurs statystyki z zastosowanie STATISTICA PL na przyktadach z medycyny, t. 3, Kraków 2007.

Szpak E., „Chory człowiek jest wtedy jak coś go boli”. Społeczno-kulturowa historia zdrowia i choroby na wsi polskiej po 1945 r., Warszawa 2016.

Timm N.H., Applied Multivariate Analysis, New York 2002.

VanPool T.L., Leonard R.D., Quantitative Analysis in Archeology, Oxford 2011.

Walesiak M., Metody analizy danych marketingowych, Warszawa 1996.

Walesiak M., Problemy decyzyjne $w$ procesie klasyfikacji zbioru obiektów, „Prace Naukowe Akademii Ekonomicznej we Wrocławiu” 1010, 2004, Ekonometria 13 , s. 52-71.

Wielkie epidemie $w$ dziejach ludzkości, red. K.F. Kiple, tłum. Z. Sidorkiewicz, Poznań 2002.

Zaremba M., Wielka trwoga: Polska 1944-1947. Ludowa reakcja na kryzys, Kraków 2012. 
Lucyna Błażejczyk-Majka

The use of cluster analysis in historical research on the example of infectious diseases incidence in districts of the Poznań Voivodeship in 1946 (Summary)

The excess of quantitative data has become more and more frequent problem in historical research, especially into the history of the nineteenth and twentieth century. Historians' task is to systematise and generalise research results and their interpretation in a broader historical context. One of the tools to assist the process of data clustering is the cluster analysis, which is a multidimensional method comparing the distance measures between the points selected on the basis of various characteristics. The method produces clusters of similar objects, and results are represented by dendrograms. A starting point for the presentation of possibilities offered by the method of the most distant neighbourhood were the statistics of infectious diseases incidences prepared in the first years after World War II by district physicians of the Poznan Voivodeship. With the use of the cluster analysis the districts of Poznań province were grouped according to different disease incidences registered for the analysed period. This, in turn, made it possible to quantitatively characterise sets of districts and confront the information with other sources. The article shows in which way quantitative methods can be used to supplement a broader historical interpretation of data on a selected socio-economic question.

Lucyna Błażejczyk-Majka - adiunkt w Zakładzie Historii Gospodarczej Instytut Historii UAM. Główny obszar zainteresowań to zastosowania metod ilościowych w badaniach historycznych oraz współczesne źródła historycznych informacji społeczno-gospodarczych.

Lucyna Błażejczyk-Majka - lecturer at the Department of Economic History of the Institute of History of Adam Mickiewicz University in Poznań. Her main research interests focus on the use of quantitative methods in historical research and contemporary historical sources of socio-economic information. E-mail: majkal@amu.edu.pl. 